\title{
Plasma FSH, LH and testosterone levels in the male rat during degeneration of the germinal epithelium caused by severe heat treatment or ligation of the vasa efferentia
}

\author{
P. M. Collins* $\dagger$, W. P. Collins, A. S. McNeilly \\ and W. N. Tsang*† \\ * Department of Zoology, St. Bartholomew's Medical College, Charterhouse Square, London; \\ $\ddagger$ Department of Chemical Pathology, St. Bartholomew's Hospital, London E.C.I, U.K.; and \\ Department of Obstetrics and Gynaecology, King's Hospital Medical School, London, S.E.5, U.K.
}

\begin{abstract}
Summary. Rats were treated by exposure of the scrotum to a temperature of $43^{\circ} \mathrm{C}$ for $30 \mathrm{~min}$ or bilateral ligation of the vasa efferentia and bled at $0,3,7,14$ and 21 days after treatment. In heat-treated rats FSH levels rose linearly from pretreatment levels while those in efferentiectomized animals remained unchanged for 3 days before increasing. In both groups FSH concentrations reached similar maximum values after 7 days and were significantly higher than those of intact controls at 7,14 and 21 days. LH levels, although not generally different from those in the controls, rose from pretreatment levels in parallel with FSH. No differences were found in testosterone concentrations in any of the groups. Histological examination at 3 weeks after treatment confirmed that the germinal epithelium consisted mainly of spermatogonia and Sertoli cells. The cytological appearance and lipid content of the Leydig cells of the aspermatogenic testes were indistinguishable from those of the controls and the weight and histological appearance of the accessory sex organs and the fructose content of the coagulating glands were also normal. It is concluded that the sterilizing effects of heat treatment and efferentiectomy are independent of changes in Leydig cell function and that the increase in gonadotrophin levels is related to the germ cell degeneration.
\end{abstract}

\section{Introduction}

The depletion of the germ cell population of the testis is accompanied by histological changes in the pituitary and an increase in the gonadotrophin content of the gland (see reviews by Burrows, 1949; Setchell, Davies \& Main, 1977). These changes have been related to a selective increase in the secretion of FSH, principally on the basis of alterations in the reproductive system of female rats joined parabiotically to sterilized males. Examination of the accessory sex organs revealed no evidence of androgen deficiency in the aspermatogenic animals and the modification in gonadotrophin secretion was attributed to the withdrawal of an inhibitory hormone normally produced by the seminiferous tubules. Subsequent re-evaluation of these concepts by using specific methods for radioimmunoassay of circulating FSH has failed to demonstrate consistently a selective increase in FSH levels following various experimental treatments which produce comparable degrees of damage to the germinal epithelium. A concurrent rise in circulating levels of FSH and LH has been recorded following X-irradiation (Main, Davies, Young \& Setchell, 1976) and cryptorchidism (Amatayakul, Ryan, Uozomi \& Albert, 1971), the two experimental procedures most commonly used by earlier workers. However, administration of antispermatogenic chemical agents has been shown to elevate plasma FSH and LH (Debeljuk, Arimura \& Schally, 1973) or to produce a selective

\footnotetext{
$\uparrow$ Present address: Department of Biological Sciences, University of California, Santa Barbara, California 93106, U.S.A

‡ Present address: MRC Unit of Reproductive Biology, 2 Forest Road Edinburgh, U.K.
} 
increase in FSH (Gomes, Hall, Jain \& Boots, 1973). FSH levels remained unaffected during the period of aspermatogenesis caused by the antimitotic agent hydroxyurea (Mecklenberg, Hetzel, Gulyas \& Lipsett, 1975) or by depriving the testis of its specific requirement for vitamin A (Krueger, Hodgen \& Sherins, 1974). This lack of uniformity in the changes in circulating gonadotrophin concentrations indicates that the pituitary response is not solely related to the interruption of spermatogenesis. Direct methods for assessing Leydig cell function in the aspermatogenic testis have also shown that defects in androgen synthesis (Llaurado \& Dominguez, 1963; Schoen, 1964) and secretion (Amatayakul et al., 1971; Gomes et al., 1973; Krueger et al., 1974) may occur even though regressive changes do not appear in the accessory sex organs for prolonged periods. Androgens also exert an inhibitory effect on the release of FSH from the pituitary (Steinberger \& Duckett, 1968). The amount of testosterone required to achieve inhibition of FSH in castrated male rats is greater than that needed to suppress LH (Swerdloff \& Walsh, 1973) and it has been suggested that a small decline in androgen production by the aspermatogenic testis could result in a preferential rise in FSH (Gomes \& VanDemark, 1974). The response of the pituitary to the interruption of spermatogenesis may therefore partly be a reflection of the degree to which Leydig cell function is also impaired.

Heat treatment and ligation of the vasa efferentia are known to produce acute atrophy of the germinal epithelium without affecting the cytological appearance of the Leydig cells or the ability of these cells to maintain various androgen-dependent features of the accessory sex organs (White, 1933; Smith, 1962; Collins \& Lacy, 1969) or to produce androgens in vitro (Collins \& Lacy, 1974). The present study was therefore undertaken to examine the effects of these two procedures for selective and local impairment of spermatogenesis on plasma FSH, LH and testosterone concentrations and thus establish the relationship between circulating gonadotrophins and spermatogenic function.

\section{Materials and Methods}

\section{Animals}

Male Wistar rats aged 48 to 50 days and weighing 200-220 g were selected for study. All 24 animals were kept at a temperature of $20 \pm 2{ }^{\circ} \mathrm{C}$ with $12 \mathrm{~h}$ light $/ 24 \mathrm{~h}$ and with unrestricted access to water and a pelleted diet. Histological examination of the testes of rats of the same age showed that the animals had completed the first wave of spermatogenesis, but that the quantitatively normal spermatogenesis, which marks the attainment of sexual maturity at Day 56 in this colony (see Tsang, Collins \& Lacy, 1973), had not yet been established. The animals were randomly allocated to 3 equal groups. Animals in Group 1 received no additional treatment and served as intact controls while rats in Groups 2 and 3 were treated as follows. In Group 2, the scrotal regions were immersed for $30 \mathrm{~min}$ in a water-bath at $43^{\circ} \mathrm{C}$ as described by Collins \& Lacy (1969). In Group 3, the vasa efferentia were bilaterally ligated under full ether anaesthesia. Incisions $(1 \mathrm{~cm})$ were made in the body wall anterior to the inguinal canal and the caput epididymidis and the pole of the testis were extruded without exposing the remainder of the testis and associated structures. The vasa efferentia were located and ligated with fine silk thread, care being taken to avoid adjacent blood vessels.

Blood samples $(2 \mathrm{ml})$ were taken from each animal, within $3 \mathrm{~min}$ of removal from its cage, by cardiac puncture under light ether anaesthesia immediately before any experimental procedures and at $3,7,14$, and 21 days after treatment. The samples were obtained between 13:00 and 15:00 $\mathrm{h}$ and immediately transferred into heparinized tubes and centrifuged. The plasma was removed and stored at $-20^{\circ} \mathrm{C}$ until assayed. This sequential sampling procedure was used to minimize variation in hormone levels which may occur when separate groups of animals are compared at different intervals for a particular treatment.

After the final blood collection the animals were weighed and decapitated. The weights of the testes, seminal vesicles (full and with their contents extruded), coagulating glands, epididymides, ventral prostate, adrenal and pituitary glands were recorded. Small pieces of tissue from the testes and the accessory sex organs were fixed in Bouin's fluid and processed routinely for histological 
examination. Additional pieces of testis were fixed in formaldehyde-saline (Baker, 1949) and embedded in gelatine. Sections were stained with Sudan black B to demonstrate the presence of lipids or subjected to the Schultz test for unsaturated sterols (Pearse, 1972).

Fructose concentrations in the coagulating glands of individual animals were determined (Mann, Davies \& Humphrey, 1949). The weight and cytological appearance of the accessory sex organs and the fructose concentrations were used as biological indices of circulating androgens.

\section{Hormone assays}

LH and FSH. Plasma levels of LH and FSH were estimated by conventional double antibody radioimmunoassays using reagents supplied by the NIAMDD, Bethesda, Maryland, U.S.A. as described previously (McNeilly \& Hagen, 1974). NIAMDD-rat-LH-I3 and rat FSH-I3 were used for iodination and results are expressed in terms of the Standard Reference preparations, NIAMDD-LHRP1 or FSH-RP1, per ml plasma. All samples were measured in duplicate in one assay. The FSH assay had an intra-assay coefficient of variation of $11 \%$ (over the range $85-500 \mathrm{ng} / \mathrm{ml}$ ) and a sensitivity of $65 \mathrm{ng} / \mathrm{ml}$. The $\mathrm{LH}$ assay had an intra-assay coefficient of variation of $8 \%$ (over the range $10-40 \mathrm{ng} / \mathrm{ml}$ ) and a sensitivity of $4 \mathrm{ng} / \mathrm{ml}$.

Testosterone. The method used was that described by Collins, Mansfield, Alladina \& Sommerville (1972). Plasma samples to which an internal standard of tritiated testosterone had been added were extracted with diethyl ether and chromatographed on a Sephadex LH-20 column. The isolated testosterone was measured in duplicate in a liquid-phase system comprising tritiated antigen and antiserum to testosterone-3-carboxymethyl oxime-bovine serum albumin. Dextran-coated charcoal was used to adsorb the unbound steroid. The principal competing steroids in this system have a hydroxyl group in the $\beta$ position at carbon 17 and the androstene- and androstanediols are completely separated by the chromatographic procedure; $17 \beta$-hydroxy- $5 \alpha$-androstan-3-one ( $5 \alpha$-dihydrotestosterone) is incompletely removed by the column and there is a maximum cross-reaction of $15 \%$ with this compound. However, circulating levels of $5 \alpha$-dihydrotestosterone are low in the rat and interference from this compound in a comparable assay system has been shown to be negligible (Falvo \& Nalbandov, 1974). The testosterone assay had an intra-assay coefficient of variation of $3 \%(20$ determinations at $0.66 \mathrm{ng} / \mathrm{ml}$ ), a sensitivity of $0.15 \mathrm{ng} / \mathrm{ml}$ and gave a mean plasma blank value of $0 \cdot 10 \mathrm{ng} / \mathrm{ml}$.

\section{Statistical analysis}

The statistical significance of differences in hormone levels were determined using the randomization test for matched pairs for comparisons within a group (Siegel, 1956a) and the randomization test for two independent samples for comparisons between groups (Siegel, 1956b). Student's $t$ test (Bailey, 1959) was used to compare mean values of organ weights and fructose concentrations.

\section{Results}

\section{Body and organ weights and fructose concentrations}

At the end of the experiment there was no significant difference between the weights of the bodies, seminal vesicles, prostate and coagulating glands, and the fructose concentrations of the animals in any of the groups (Table 1). The volume of secretion in the seminal vesicles was also unaffected, as judged by the weight of fluid which could be extruded from the gland. The weights of the testes and epididymides of rats in Groups 2 and 3 were significantly lower than those of Group 1, while the weights of the pituitary glands were significantly higher.

\section{Histology}

The pattern of testicular degeneration was similar for the animals in Groups 2 and 3: the germinal epithelium in most of the tubules was represented only by spermatogonia, and cells indicative of further development (resting, leptotene and zygotene spermatocytes) were seen only in occasional tubules. No degenerative changes were apparent in the Sertoli cells and the nuclei of these cells formed a prominent layer close to the basement membrane (Pl. 1, Figs 5 and 6). There was an increase in the lipid content of the Sertoli cells which also gave a positive reaction for unsaturated sterols (Pl. 1, Figs 3 and 4). 
Table 1. Mean \pm s.e.m. body and organ weights and fructose concentrations in rats (8/group)

\begin{tabular}{|c|c|c|c|}
\hline & $\begin{array}{c}\text { Group 1 } \\
\text { (intact control) }\end{array}$ & $\begin{array}{c}\text { Group } 2 \\
\text { (heat-treated) }\end{array}$ & $\begin{array}{c}\text { Group 3 } \\
\text { (efferentiectomized) }\end{array}$ \\
\hline \multicolumn{4}{|l|}{ Weights } \\
\hline Body (g) & $332 \pm 4$ & $359 \pm 6$ & $349 \pm 11$ \\
\hline Testes $(\mathrm{g})$ & $3.31 \pm 0.09$ & $1 \cdot 22 \pm 0.05^{* * *}$ & $2 \cdot 33 \pm 0 \cdot 17^{* * *}$ \\
\hline Epididymides (g) & $1.09 \pm 0.03$ & $0.69 \pm 0.03^{* * *}$ & $0.74 \pm 0.03^{* * *}$ \\
\hline Seminal vesicles $(\mathrm{g})$ & $0.86 \pm 0.05$ & $0.74 \pm 0.06$ & $0.94 \pm 0.06$ \\
\hline Seminal vesicle contents (g) & $0.53 \pm 0.04$ & $0.46 \pm 0.05$ & $0.59 \pm 0.05$ \\
\hline Coagulating glands $(\mathrm{g})$ & $0.19 \pm 0.02$ & $0.19 \pm 0.02$ & $0.23 \pm 0.03$ \\
\hline Ventral prostate gland (g) & $0.42 \pm 0.02$ & $0.39 \pm 0.03$ & $0.48 \pm 0.03$ \\
\hline Adrenal glands (mg) & $50 \cdot 5 \pm 2 \cdot 8$ & $47 \cdot 8 \pm 2 \cdot 6$ & $56 \cdot 7 \pm 2.9$ \\
\hline Pituitary gland (mg) & $9.7 \pm 0.4$ & $11 \cdot 6 \pm 0.5 *$ & $11.2 \pm 0.3 * *$ \\
\hline Fructose content of coagulating glands $(\mathrm{mg} / 100 \mathrm{~g})$ & $113 \pm 8$ & $116 \pm 9$ & $109 \pm 9$ \\
\hline
\end{tabular}

${ }^{*} P<0.025,{ }^{* *} P<0.05,{ }^{* * *} P<0.001$, compared with intact controls (Student's $t$ test).

The appearance of the Leydig cells in the treated animals in Groups 2 and 3 was indistinguishable from that seen in Group 1 animals. The Leydig cells had round nuclei with a prominent nucleolus in a clear nuclear matrix (Pl. 1, Figs 5 and 6) and the cytoplasm contained a small amount of lipid which did not give a positive response for unsaturated sterols (Pl. 1, Figs 3 and 4). These features are characteristic of the active Leydig cell of the sexually mature rat (Tsang, Lacy \& Collins, 1973).

The histological appearance of tissue from the seminal vesicles, coagulating and ventral prostate glands was similar in all 3 groups (PI. 1, Figs 7 and 8).

\section{Hormone concentrations}

$F S H$. The changes in plasma FSH concentrations are shown in Table 2. FSH values declined progressively in Group 1 rats, but were significantly higher in Groups 2 and 3 on Days 7, 14 and 21 after treatment. In Groups 2 and 3, maximum values were obtained on Day 7 after treatment.

\section{EXPLANATION OF PLATE 1}

Photomicrographs of tissues from control rats (Group 1) and rats killed 3 weeks after heat treatment (Group 2) or bilateral ligation of the vasa efferentia (Group 3).

Fig. 1. Testis of a Group 1 rat. Full spermatogenesis is established and normal numbers of maturation-phase spermatids and associated residual bodies are present near the lumen of the seminiferous tubule. Ironhaematoxylin and orange G. $\times 130$.

Fig. 2. Testicular lipid distribution in a Group 1 rat. Small amounts of lipid are present near the periphery of the seminiferous tubule, while that in the Leydig cells is typical of the functional adult cell. Sudan-black B. $\times 130$.

Figs 3 and 4. Testicular lipid in a Group 2 (Fig. 3) and a Group 3 (Fig. 4) rat. Large amounts of lipid have accumulated in the seminiferous tubules, but the lipid content of the Leydig cells in unchanged from the low levels seen in Group 1 animals. Sudan-black B. $\times 140$.

Fig. 5. Testis of a Group 2 rat. The seminiferous tubules contain only Sertoli cells and spermatogonia but no degenerative changes are apparent in the interstitial tissue. Iron-haematoxylin and orange G. $\times 140$.

Fig. 6. Testis of a Group 3 rat. The condition is similar to that in Fig. 5 ; there is no germ cell development beyond the spermatogonial stage but abundant and histologically normal interstitial tissue is present in the intertubular space. Iron-haematoxylin and orange G. $\times 140$.

Figs 7 and 8. The cytological appearance of the epithelial cells of the ventral prostate gland in Group 2 (Fig. 7) and Group 3 (Fig. 8) rats is typical of normal adult tissue. The presence of a well defined supranuclear clear zone in the epithelial cells and large amounts of acidophilic secretory material in the lumen of the alveolus are characteristic of the actively secreting gland. Iron-haematoxylin and orange $\mathbf{G}$. $\times 140$. 


\section{PLATE}
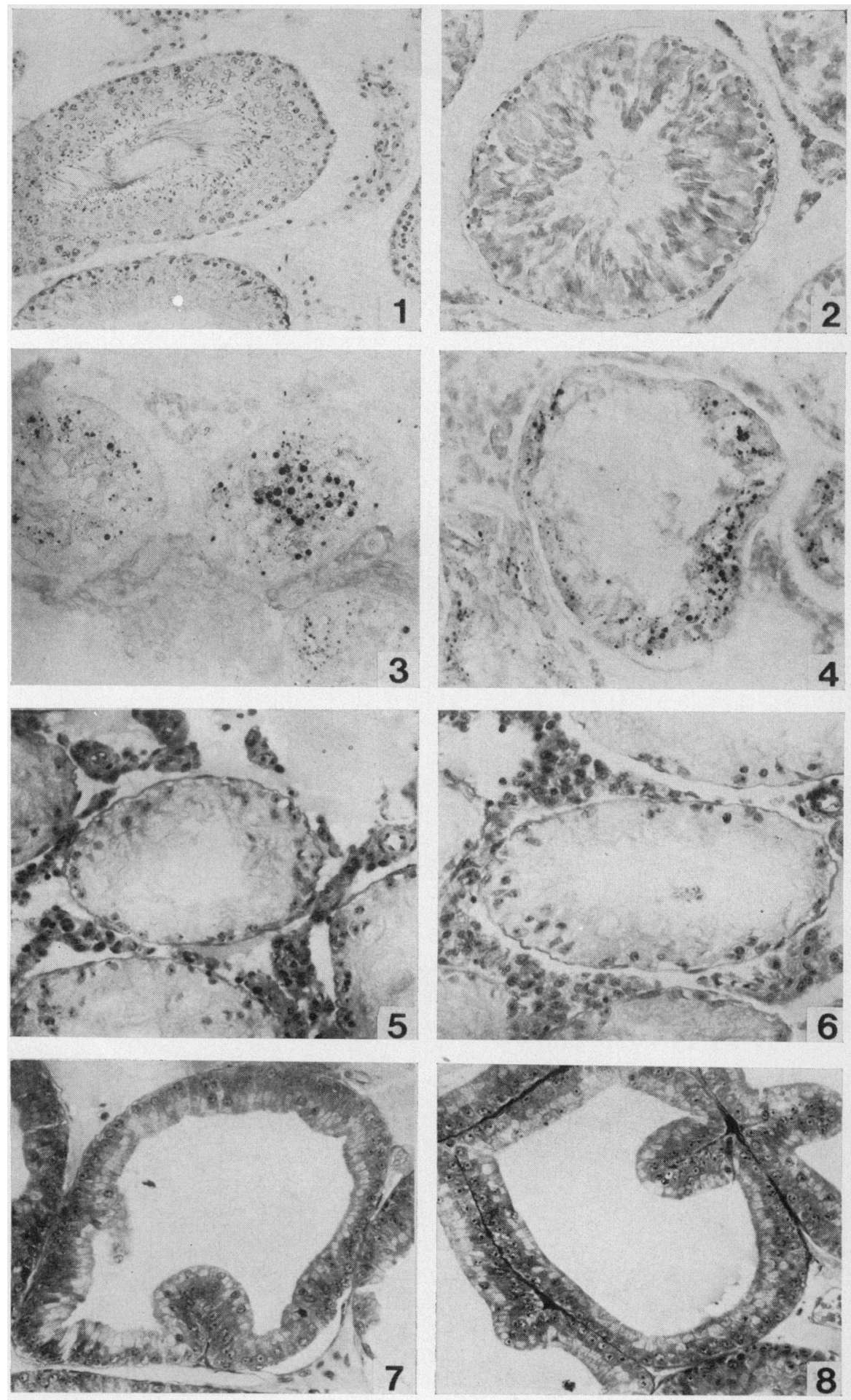
Table 2. Concentrations (mean \pm s.e.m.) of FSH, $\mathbf{L H}$ and testosterone in plasma samples taken sequentially from individual rats (8/group)

\begin{tabular}{|c|c|c|c|c|}
\hline Group & $\begin{array}{l}\text { Days after } \\
\text { treatment }\end{array}$ & $\begin{array}{l}\text { FSH (ng NIAMDD- } \\
\text { FSH-RP1/ml) }\end{array}$ & $\begin{array}{c}\text { LH (ng NIAMDD- } \\
\text { LH-RP1/ml) }\end{array}$ & $\begin{array}{l}\text { Testosterone } \\
\quad(\mathrm{ng} / \mathrm{ml})\end{array}$ \\
\hline 1 (intact) & $\begin{array}{r}0 \\
3 \\
7 \\
14 \\
21\end{array}$ & $\begin{array}{l}697 \pm 59 \\
683 \pm 70 \\
616 \pm 66 \\
507 \pm 37^{*} \\
510 \pm 60^{*}\end{array}$ & $\begin{array}{l}39 \pm 7 \\
44 \pm 6 \\
46 \pm 9 \\
38 \pm 2 \\
34 \pm 5\end{array}$ & $\begin{array}{l}1.82 \pm 0.33 \\
2.64 \pm 0.36 \\
3.12 \pm 0.71 \\
2.74 \pm 0.46 \\
3.24 \pm 0.31\end{array}$ \\
\hline 2 (heat-treated) & $\begin{array}{r}0 \\
3 \\
7 \\
14 \\
21\end{array}$ & $\begin{array}{l}674 \pm 32 \\
851 \pm 133 \\
887 \pm 66^{*} \dagger \\
792 \pm 111 \dagger \\
733 \pm 115 \dagger\end{array}$ & $\begin{array}{l}33 \pm 5 \\
42 \pm 11 \\
58 \pm 6^{* *} \\
61 \pm 17^{*} \\
49 \pm 5^{*}\end{array}$ & $\begin{array}{l}1.67 \pm 0.37 \\
3.34 \pm 0.81 \\
2.88 \pm 0.32 \\
1.72 \pm 0.38 \\
3.16 \pm 0.94\end{array}$ \\
\hline 3 (efferentiectomized) & $\begin{array}{r}0 \\
3 \\
7 \\
14 \\
21\end{array}$ & $\begin{array}{l}628 \pm 27 \\
608 \pm 47 \\
912 \pm 57^{* * *} \dagger \dagger \\
800 \pm 60^{*} \dagger+\dagger \\
765 \pm 46^{*}+\dagger\end{array}$ & $\begin{array}{l}29 \pm 5 \\
30 \pm 4 \\
62 \pm 5^{* * *} \\
53 \pm 4^{* *} \dagger \dagger \\
42 \pm 8\end{array}$ & $\begin{array}{l}2.46 \pm 0.54 \\
2.93 \pm 0.53 \\
3.58 \pm 0.69 \\
2.82 \pm 0.30 \\
3.41 \pm 0.72\end{array}$ \\
\hline
\end{tabular}

Significantly different from pretreatment values, ${ }^{*} P<0.05 ;{ }^{* *} P<0.01 ; * * * P<0.001$.

Significantly different from corresponding values in Group $1+P<0.05 ; \dagger+P<0.01 ; \dagger+\uparrow P<0.001$.

$L H$. Within Groups 2 and 3, maximum values were seen on Day 7 after treatment, but only the Day-14 value in Group 3 was significantly different from the corresponding value in Group 1.

Testosterone. There were no significant differences in plasma testosterone levels within or between the three groups.

\section{Discussion}

The present results confirm that, in spite of the acute degeneration of the germinal epithelium which follows heat treatment and ligation of the vasa efferentia, the Leydig cells are unaffected: they retain the cytological features and low lipid content characteristic of the actively secreting cell, circulating levels of testosterone remained unchanged, and the accessory sex organs appear normal.

Attempts to relate changes in circulating FSH levels to the condition of the seminiferous tubules following different experimental procedures have variously implicated the meiotic spermatocytes (Gomes et al., 1973), the young spermatids (Debeljuk et al., 1973) or mature spermatozoa (Swerdloff, Walsh, Jacobs \& Odell, 1971) in the regulation of FSH secretion. The present work showed that there is a difference in the pattern of early changes in FSH concentration between heat-treated and efferentiectomized animals. In the heat-treated rats (Group 2) FSH values rose rapidly (but insignificantly) from their pretreatment level while those in the efferentiectomized animals (Group 3) remained unchanged until Day 7. Collins \& Lacy (1969) have shown that exposure of the scrotum to a temperature of $43^{\circ} \mathrm{C}$ for $30 \mathrm{~min}$ almost completely destroys the primary spermatocyte population and causes extensive and characteristic damage to spermatids within 3 days of treatment and by 7 days the germinal epithelium is reduced mainly to Sertoli cells and spermatogonia. After ligation of the vasa efferentia, however, there is a period of testicular enlargement as fluid and germinal products accumulate in the tubules and no consistent reduction in the population of any cell type occurs before $72 \mathrm{~h}$ (Smith, 1962). From these data it may be concluded that the initial rise of FSH in Groups 2 and 3 coincides with the onset of the rapid regression of the germinal epithelium and that maximum values are attained when degeneration of the germ cells is well advanced. The FSH concentrations may therefore be related to the pattern of germ cell degeneration rather than to the presence or absence of particular cell type. 
In the control animals, FSH gradually declined to a level $30 \%$ below the initial value after 2 weeks. The magnitude and rate of decline in FSH concentrations in the control animals in the present study correspond closely to the values recorded by Swerdloff et al. (1971), who have described a fall in FSH concentration from a maximal prepubertal value, 2-3 times the adult level, which continued until sexual maturation was complete.

At the point of maximum elevation FSH levels in the heat-treated and the efferentiectomized animals were $48 \%$ and $44 \%$ higher, respectively, than the corresponding control values. Differences of the same order of magnitude have been reported after treatment with antispermatogenic chemical agents (Debeljuk et al., 1973; Gomes et al., 1973) and X-irradiation (Bain \& Keene, 1975). When compared with the 5 - to 10-fold increases in FSH which occur after castration (Amatayakul et al., 1971; Gay \& Dever, 1971; Swerdloff \& Walsh, 1973) the pituitary response to the destruction of the germinal epithelium is extremely limited and the Leydig cells, Sertoli cells and spermatogonia presumably retain a major inhibitory influence on adenohypophysial function. The reason for the unchanged FSH levels in rats treated with hydroxyurea (Mecklenburg et al., 1975) or a vitamin A-deficient diet (Krueger et al., 1974) when only the Sertoli cells and spermatogonia remain in the tubules cannot be explained but may be partly due to the chronic nature of the testicular changes induced by the procedures and the large variation in FSH levels reported between animals in the different experimental groups.

In addition to providing negative feedback control for $\mathrm{LH}$, testosterone can prevent or reverse the rise in plasma FSH concentrations in castrated male rats at dose levels which are either pharmacological (Steinberger \& Duckett, 1968; Gay \& Dever, 1971; Swerdloff \& Walsh, 1973) or physiological (Crim \& Geschwind, 1972; Eldridge \& Mahesh, 1974) in terms of the amount needed to maintain normal blood levels (Verjans, van der Molen \& Eik-Nes, 1975). Conversely, large increases in serum FSH concentrations are found after a reduction in levels of low-affinity bound testosterone by administration of anti-testosterone serum (Main, Davies \& Setchell, 1977) or in cryptorchidism in which germ cell degeneration is accompanied by a decline in circulating testosterone (Amatayakul et al., 1971). These results, and the apparent normality of Leydig cell function in the present experiments, suggest that testosterone plays a physiological role in the feed-back regulation of FSH, and that the Leydig cells may account for a major part of the residual inhibition of FSH by the sterilized testes and serve to limit the pituitary response to sterilization. The elevation of FSH after degeneration of the germinal epithelium in this study was not selective but was accompanied by a collateral rise in LH. This lack of dissociation in the response of FSH and LH to germ cell destruction has been noted by others (Debeljuk et al., 1973; Amatayakul et al., 1974; Main et al., 1976).

The present data support the hypothesis that an inverse relationship exists between spermatogenic activity and plasma FSH concentrations. However, the concept of an independent mechanism for the feedback regulation of FSH by the seminiferous tubules, as envisaged in the original inhibin hypothesis (McCullagh, 1932), requires modification to account for the influence of the state of the germinal epithelium on plasma levels of FSH and LH in the adult rat.

It is a pleasure to acknowledge the financial support of Schering Chemicals, the Wellcome Trust and the Joint Research Board of St. Barthlomew's Hospital and Medical College.

\section{References}

Amatayakul, K., Ryan, R., Uozomi, T. \& Albert, A. (1971) A reinvestigation of testicular-anterior pituitary relationships in the rat. I. Effects of castration and cryptorchidism. Endocrinology 88, 872-880.

BaILEY, N.Y.J. (1959) The use of t-tests for small samples. In Statistical Methods in Biology, pp. 43-51. English Universities Press, London.
BaIN, J. \& KeENE, J. (1975) Further evidence for inhibin: change in serum luteinizing hormone and folliclestimulating hormone after X-irradiation. J. Endocr. 66, 279-280.

BAKER, J.R. (1949) Further remarks on the Golgi element. Q. Jl Microsc. Sci. 90, 293.

Burrows, H. (1949) Factors which influence the gonadotrophic activity of the pituitary. In Biological Actions Downloaded from Bioscientifica.com at 04/26/2023 12:11:56PM 
of Sex Hormones, 2nd edn, pp. 40-82. Cambridge University Press.

Collins, P. \& LACY, D. (1969) Studies on the structure and function of the mammalian testis. II. Cytological and histochemical observations on the testis of the rat after a single exposure to heat applied for different lengths of time. Proc. $R$. Soc. B 172, 17-38.

Collins, P. \& LACY, D. (1974) Studies on the structure and function of the mammalian testis. IV. Steroid metabolism in vitro by isolated interstitium and seminiferous tubules of rat testis after heat sterilization. Proc. R. Soc. B 186, 37-51.

Collins, W.P., Mansfield, M.D., Alladina, N.S. \& SOMMERVILLE, I.F. (1972) Radioimmunoassay of plasma testosterone. J. Steroid Biochem. 3, 333-348

CrIm, L.W. \& Geschwind, I.I. (1972) Patterns of FSH and $\mathrm{LH}$ secretion in the developing ram : the influence of castration and replacement therapy with testosterone propionate. Biol. Reprod. 7, 47-54.

Debeljuk, L., Arimura, A. \& Schally, A.V. (1973) Pituitary and serum FSH levels after massive and selective depletion of the germinal epithelium in the rat testis. Endocrinology 92, 48-54.

Eldridge, J.C. \& MAHesh, V.B. (1974) Pituitary-gonadal axis before puberty: evaluation of testicular steroids in the male rat. Biol. Reprod. 11, 385-397

Falvo, R.E. \& Nalbandov, A.V. (1974) Radioimmunoassay of peripheral plasma testosterone in males from eight species using a specific antibody without chromatography. Endocrinology 95, 1466-1468.

GAY, V.L. \& DEVER, N.W. (1971) Effects of testosterone propionate and estradiol benzoate alone or in combination on serum LH and FSH in orchidectomized rats. Endocrinology 89, 161-168.

Gomes, W.R. \& VANDemark, N.L. (1974) The male reproductive system. A. Rev. Physiol. 36, 307-330.

Gomes, W.R., Hall, R. W., Jain, S. K. \& Boots, L.R. (1973) Serum gonadotropin and testosterone levels during loss and recovery of spermatogenesis in rats. Endocrinology 93, 800-809.

KRUeger, P.M., Hodgen, G.D. \& Sherins, R.J. (1974) New evidence for the role of the Sertoli cell and spermatogonia in feedback control of FSH secretion in male rats. Endocrinology 95, 955-962.

Llaurado, J.G. \& Dominguez, O.V. (1963) Effect of cryptorchidism on testicular enzymes involved in androgen biosynthesis. Endocrinology 72, 292-295.

Main, S.J., Davies, R.V., Young, M.G.W.L. \& SETChell, B.P. (1976) Serum and pituitary gonadotrophins after destruction of germinal cells in the testis by X-irradiation or heat. $J$. Endocr. $69,23 P$.

Main, S.J., Davies, R.V. \& Setchell, B.P. (1977) The effect of injections of an antiserum to testosterone on serum gonadotrophins and testosterone in rats. J. Endocr. 72, $22 P$.

ManN, T., Davies, D.V. \& Humphrey, G.F. (1949) Fructose and citric acid assay in the secretions of the accessory glands of reproduction as indicator tests of male sex hormone activity. $J$. Endocr. 6, 75-85.

MCCullaGH, D.R. (1932) Dual endocrine activity of the testes. Science, N.Y. 76, 19-20.

McNeilly, A.S. \& Hagen, S. (1974) Prolactin, TSH, LH and FSH responses to a combined LHRH/TRH test at different stages of the menstrual cycle. Clin. Endocr. 3, 427-435.

Mecklenberg, R.S., Hetzel, W.D., Gulyas, B.J. \& LIPSETT, M.B. (1975) Regulation of FSH secretion: use of hydroxyurea to deplete germinal epithelium. Endocrinology 96, 564-570.

Pearse, A.G.V. (1972) Histochemistry: Theoretical and Applied. Churchill Livingston, Edinburgh.

SCHOEN, E.J. (1964) Effect of local irradiation on testicular androgen biosynthesis. Endocrinology 75, 56-65.

Setchell, B.P., Davies, R.V. \& MaIN, S.J. (1977) Inhibin. In The Testis, Vol. 4, pp. 189-238. Eds A. D. Johnson \& W. R. Gomes. Academic Press, New York.

Siegel, S. (1956a) The case of two related samples. In Non-Parametric Statistics, pp. 61-94. Ed. H. F. Harlow. McGraw-Hill, New York.

SiEgEL, S. (1956b) The case of two independent samples. In Non-Parametric Statistics, pp. 95-158. Ed. H. F. Harlow. McGraw-Hill, New York.

Smirh, G. (1962) The effects of ligation of the vasa efferentia and vasectomy on testicular function in the adult rat. $J$. Endocr. 23, 385-399.

Steinberger, E. \& DucketT, G. (1968) Effect of testosterone propionate on the release of FSH from the pituitary gland. Acta endocr., Copenh. 57, 289-295.

Swerdloff, R.S. \& WALSh, P.C. (1973) Testosterone and oestradiol suppression of $\mathrm{LH}$ and FSH in adult male rats: duration of castration, duration of treatment and combined treatment. Acta endocr., Copenh. 73, 11-21

SWerdloff, R.S., WAlsh, P.C., JACOBS, H.S. \& ODELL, W.D. (1971) Serum LH and FSH during sexual maturation in the male rat: effect of castration and cryptorchidism. Endocrinology 88, 120-128.

TSANG, W.N., Collins, P.M. \& LACY, D. (1973) Steroid metabolism by the seminiferous tubules in vitro and spermatogenesis in the developing rat. $J$. Reprod. Fert. 34, 513-517.

Tsang, W.N., LaCY, D. \& Collins, P.M. (1973) Leydig cell differentiation, steroid metabolism by the interstitium in vitro and the growth of the accessory sex organs in the rat. $J$. Reprod. Fert. 34, 353-355.

VerJans, H.L., VAN der Molen, H.J. \& EIK-Nes, K.B. (1975) Relation between circulating levels of testosterone, LH and FSH in intact and castrated, adult male rats after testosterone administration. Acta endocr., Copenh. 79, 380-386.

White, W.E. (1933) The duration of fertility and the histological changes in the reproductive organs after ligation of the vasa efferentia in the rat. Proc. $R$. Soc. B 113, 544-550. 